\title{
New Find of Six-Spoke Sun Wheels from the Bronze Age in Scandinavia
}

\author{
Nils-Axel Mörner1 ${ }^{*}$, Bob G. Lind ${ }^{2}$ \\ ${ }^{1}$ Paleogeophysics \& Geodynamics, Stockholm, Sweden \\ ${ }^{2}$ Archaeoastronomy, Malmö, Sweden \\ Email: *morner@pog.nu
}

How to cite this paper: Mörner, N.-A. and Lind, B.G. (2018) New Find of Six-Spoke Sun Wheels from the Bronze Age in Scandinavia. International Journal of Astronomy and Astrophysics, 8, 299-305. https://doi.org/10.4236/ijaa.2018.84021

Received: October 6, 2018

Accepted: November 4, 2018

Published: November 7, 2018

Copyright (c) 2018 by authors and Scientific Research Publishing Inc. This work is licensed under the Creative Commons Attribution International License (CC BY 4.0).

http://creativecommons.org/licenses/by/4.0/

\begin{abstract}
Six-spoke Sun wheels have previously been described by us from Mesopotamia, rock-carvings in Sweden and a golden sky dome from Sweden. The division of the Sun wheel into six segments refers to the six double-months of 60 days, and a full annual cycle of 360 days. In this paper we report the findings of a stone carving with 9 six-spoke Sun wheels and two solar eclipses found and depicted in 1840 in Denmark. The spokes in the nine Sun wheels are in N-S, E-W and NW-SE direction. The NW-SE line co-insides with the sunset at summer solstice and sunrise at winter solstice, which is in full agreement with the alignment of the famous stone-ship of Ales Stones in southernmost Sweden. The new stone carving in Denmark provides a confirmation of the deep knowledge in astronomy existing among the Bronze Age people, all from Mesopotamia up the Scandinavia.
\end{abstract}

\section{Keywords}

Sun Wheel, Stone Carving, Archaeoastronomy, Ales Stones, Scandinavia

\section{Introduction}

We have published a number of papers on astronomical monuments and object from the Bronze Age in Sweden [1]-[11], out of those papers the last two [10] and [11] referred to the six-spoke Sun wheel found on "the Golden Sky Dome from Mjövik" in SE Sweden, the rock-carving at Stora Backa at Brastad in SW Sweden and on a stone tablet from the ancient Sun-temple at Sippar in Mesopotamia. All these three objects are from the Bronze Age.

The six-spoke Sun wheel symbols record the course of a year in six segments all representing 60 days per segment and 360 days in total for the whole year (as further discussed in papers [10] and [11]). It was a novel finding calling for ex- 
tended research.

Therefore, one of us (B.G.L) stated an investigation of Scandinavian rock-carvings and ornaments on Bronze Age objects in Scandinavia. And, lo and behold, he soon found what he was searching for. In the National Museum in Copenhagen, there was an old drawing from the 1840s showing 9 six-spoke Sun wheels [12] [13]. In this paper, we will for the first time describe this object, its origin, history and implication for our understanding of Bronze Age astronomy.

\section{A Bronze Age Mound at Høbbehøjen in Denmark}

The Bronze Age mound at Høbbehøjen was in today's Vestre Sæby on Sjælland (Figure 1). The mound included two burial chambers. In the southern chamber, there were human bones, not burned, a large number of flint object and numerous pieces of yellow amber. In the northern chamber, there was a lot of soot from cremation, and remains of a horse, which might have followed his master in death. The image stone here described was found in the southern grave.

The grave was found in 1840 and excavated by the nearby estate owner Count J. Raben in his hunting for gold. An image stone was found, but ignored by the gold hunting count.

\subsection{A Stone with Rock Carvings}

The rumor of the image stone reached Copenhagen in a few days, however. The Danish war councilor S. Schiøtz heard about it and immediately travelled to the site, where he made a careful drawing of the stone and its rock carvings. In 1842, he gave the drawing to the National Museum in Copenhagen (on October 6, 1842), where it has been lying since then with little recognition [12] [13] up to this paper.

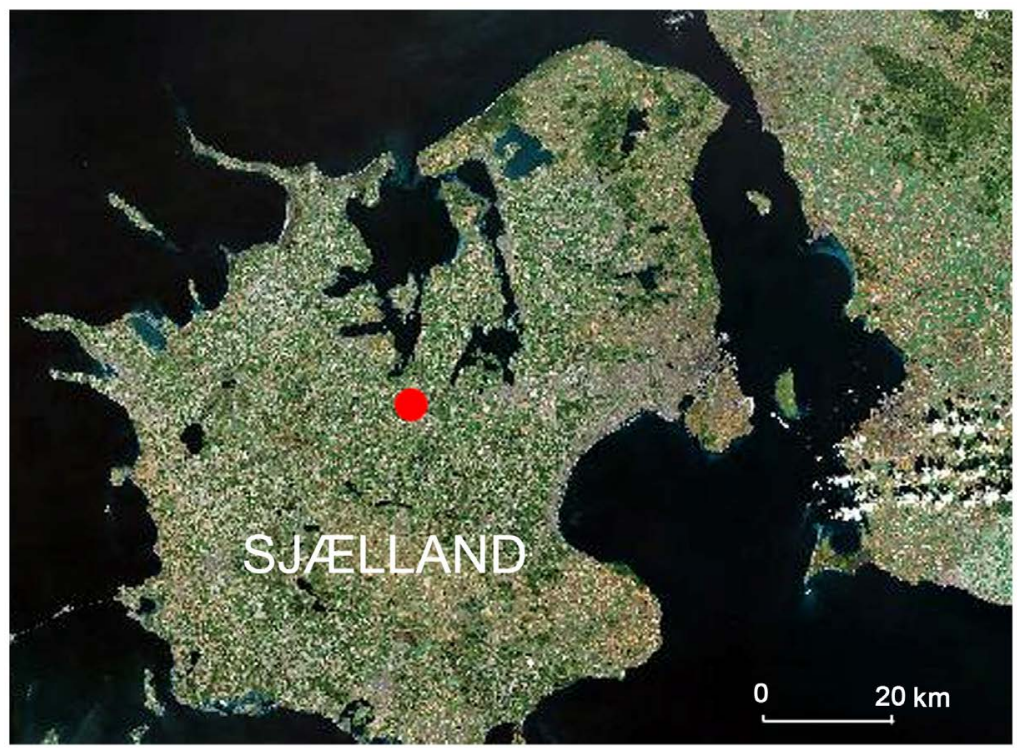

Figure 1. Location of Høbbehøjen at today’s Vestre Sæby on Sjælland in Denmark. 


\subsection{A Remarkable Bronze Age Image}

The rock carvings on the Høbbehøjen image stone are quite remarkable (Figure 2). A group of 9 six-spoke Sun wheels are shown together with two semilunar arcs. The 9 Sun wheels are obvious analogues to the ones described on "the Golden Sky Dom of Mjövik", the rock carving at Stora Backa in Brastad and from the Sun-temple at Sippar in Mesopotamia as discussed in [10] and [11].

All the 9 Sun wheels consist of a circle, which is crossed by three lines; one in $\mathrm{N}-\mathrm{S}$ direction, one in $\mathrm{E}-\mathrm{W}$ direction and one in NW-SE direction. The one in NW-SE is of special interest as it co-insides with the direction of sunset at summer solstice in NW and of sunrise at winter solstice in SE (whilst this is the case in sun wheals $1,4,5,7$ and 8 , the diagonal line is somewhat steeper in sun wheels 2, 3, 6 and 9, a variation which probably belongs to the drawing).

The two semilunar arcs are likely to represent solar eclipses.

Eight of the nine Sun wheels are well ordered in rows. The 9th position is taken by a symbol of an eclipse and the ninth Sun wheel is pushed aside. This cannot have been done without a reason.

\subsection{A Sad Vandalizing}

The farmer owning the ground of the Høbbehøjen mound destroyed the mound with its graves and image stones. He is said to have blown it up with gunpowder. Therefore, the only image left is the one made by Schiøtz in 1840 and handed in to the National Museum in 1842 (plus the drawing by geologist Steenstrup made of another image stone and handed in to the National Museum in 1887).

\section{Interpretations}

The six-spoke Sun wheels we interpret in terms of annual solar calendars composed of six 60 days segments making a full annual cycle of 360 days, like we did with the other six-spoke objects [10] [11]. It is a manifestation of the sexagesimal

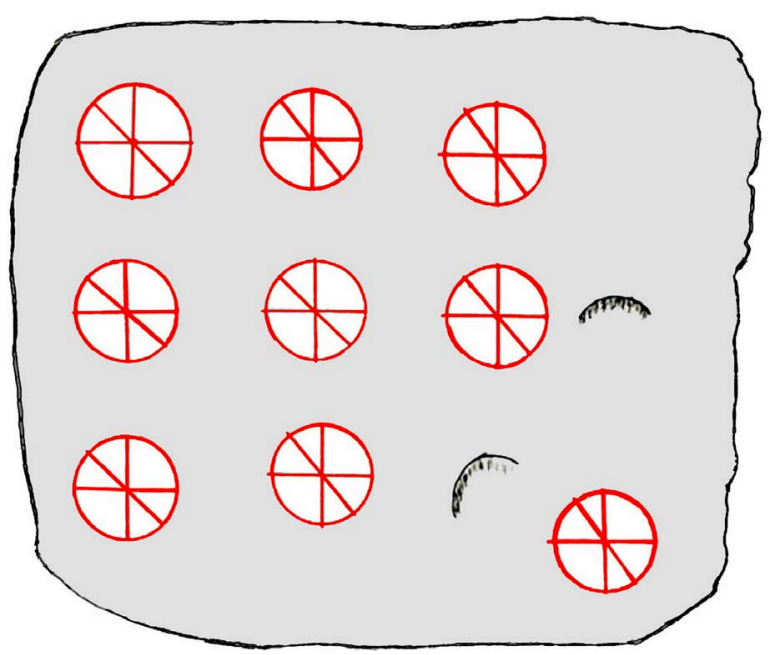

Figure 2. The 9 six-spoke Sun wheels and 2 solar eclipses on the image stone in the Bronze Age mound at Høbbehøjen as drawn by Schiøtz in 1840. 
mathematical system originating in Mesopotamia [14]. The two semilunar arcs, we interpret in terms of solar eclipses. So far the interpretations agree well with previously described objects [10] [11].

The arrangements of the 9 solar symbols and the 2 eclipse symbols on the image stone (Figure 2) call for additional interpretation.

One six-spoke Sun wheel represents an annual calendar of one year. Therefore, it seems highly likely that the 9 Sun wheels represent 9 years.

On the Høbbehøjen image stone (Figure 2), there are 8 very well ordered Sun wheels, and then a 9th one dislocated to the side by the appearance of one of the semilunar arc symbols. Therefore, it seems that something unusual happened every 9 th year.

According to Henriksson [15], Sjælland experienced 3 total solar eclipses in the Bronze Age, viz. at 858, 1521 and 1596 BC, implying that an interpretation in terms of solar eclipses may well be correct, though still unconfirmed.

\subsection{Magic of Number 9}

Obviously, number 9 had some special implications in ancient belief and handling. Zeus and Mnemosyne had 9 daughters, the Nine Muses, all goddesses of music, poetry, art and science. In the Asa Cred, nine was a very important number. In order to obtain all earthly and spiritual knowledge, the God Odin had to hang in the world-tree Yggdrasil for 9 sun-days and 9 moon-nights. His son Heimdall, the Sun-god, was born by 9 virgin mothers at the sun rise at the horizon of the sea.

Adam of Brehmen [16] mentioned that, at the holy place at Leire on Sjælland in Denmark, extensive feasts were performed every 9th year at winter solstice. The feast went on for 9 days and every day one person and 7 animals were sacrificed. He also describes sacrifice rite at Uppsala in Sweden. At winter solstice, 9 humans and animals of masculine gender were sacrificed, and then hanged up in trees close to the temple [16].

Therefore, we believe that there was something special and magic with number 9 from the Bronze Age and into the Late Iron Age. It seems that this is some sort of background to the carving of 9 Sun wheels on the Høbbehøjen image stone (Figure 2).

\subsection{Solar Alignment}

Ales Stones is a remarkable monument of clear astronomical dimensions in Southern Sweden [2] [9] [11]. The form is a stone ship of 69 meter's length, and it is strictly aligned in NW-SE direction: i.e. in the straight line of sunrise at winter solstice in the SE and of sunset at summer solstice in the NW. The arrangements of the side-stones give 11 months of 30 days and 1 month (July) of 35 days, giving a full year of 365 days.

The NW-SE line in the Sun wheels of Høbbehøjen has exactly the angle with respect to N-S and E-W as the symmetry axis of Ales Stones (Figure 3). 
(a)
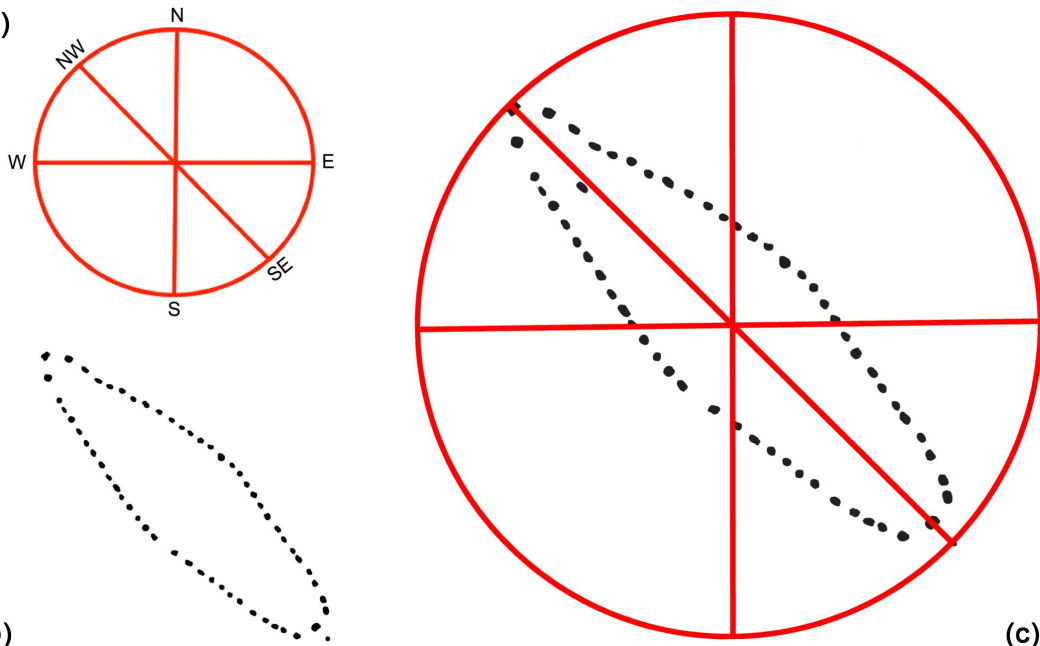

(b)

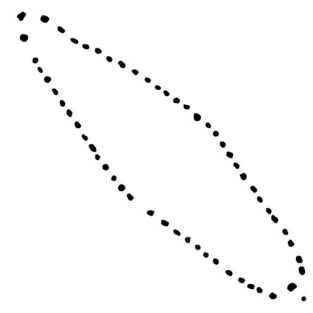

(c)

Figure 3. The NW-SE line in the 9 Sun wheels of (a) has the same angle as the long-axis of Ales Stones (b); and when superposed there is a perfect agreement (c). This lends strong support to a cultural connection. The Høbbehøjen symbol has a diameter of 10 $20 \mathrm{~cm}$, whist the Ale Stones are $69 \mathrm{~m}$ long and $19 \mathrm{~m}$ wide.

\subsection{Geographical Impact}

Six-spoke Sun wheel are now found in the Sun temple in Sippar in Mesopotamia, on the Golden Sky Dome of Mjövik in SE Sweden, on the rock carving at StoraBacka (Brastad) in SW Sweden, and the stone carving at Høbbehøjen in Denmark (Figure 4). Ales Stones are closely related because of its deep astronomical principles.

This implies that the astronomical knowledge was well established in the Bronze Age all from Mesopotamia to Scandinavia.

There is still another six-spoke Sun wheel: the Golden Sun-disk from Glüsing in Schleswig-Holstein [17], but the original is so fragmentary [18] that the reconstruction remains hypothetical.

\section{Conclusions}

A new astronomical image from the Bronze Age is presented. The image (a drawing from 1840) was found in the archive of the Natural Museum in Copenhagen [12] [13], where it has been lying for 174 years without any deeper analysis.

It shows 9 six-spoke Sun wheels and two semilunar arcs. The Sun symbols agree well with our previous described objects with six-spoke Sun wheels [10] [11].

The spokes are not equally distributed in the wheel. Besides a vertical and a horizontal line, there is a diagonal line in NW-SE. This line co-insides with the symmetry line of Ales Stones, and the straight line between sunrise at winter solstice in the SE and the sunset at summer solstice in the NW: i.e. the solar motion over the sky during a year, backing up the interpretation that we are dealing with Sun wheels. 


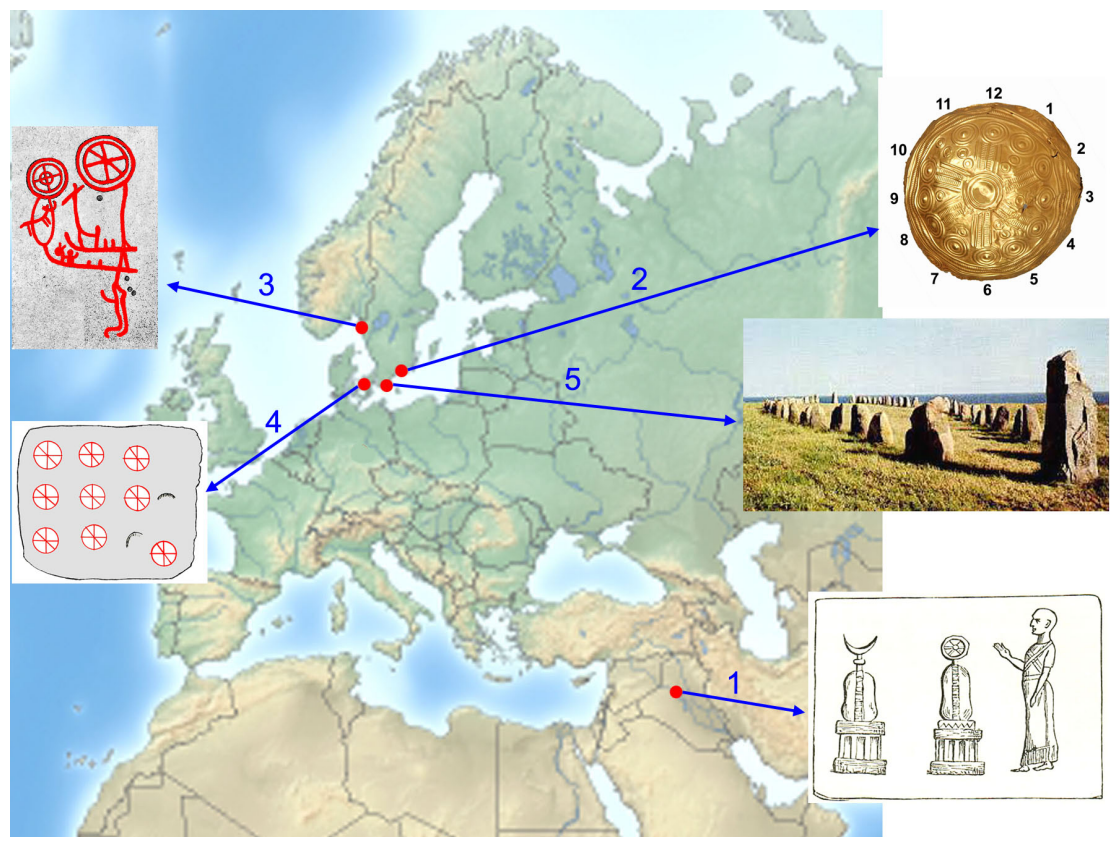

Figure 4. Geographical location of the five objects discussed, indicating that the Bronze Age people had a deep knowledge in astronomy all from Mesolotamia (1) to Scandinavia $(2-5)$.

The geographical distribution of six-spoke Sun wheels (Figure 4) indicates the wide spread in the Bronze Age of this symbol of Sun cult [11] all from Mesopotamia to Scandinavia in the northwest.

\section{Conflicts of Interest}

The authors declare no conflicts of interest regarding the publication of this paper.

\section{References}

[1] Henriksson, G. (1999) Prehistoric Constellation on Swedish Rock-Carvings. Actes Vème Conference, Gdansk, 5-8 September 1997, 155-173.

[2] Lind, B.G. (2005) Alesstenar som solkalendarium. Ale, 4, 21-24.

[3] Mörner, N.-A., Lind, B.G. and Possnert, G. (2009) Heimdall's Stonesat Vitemölla in SE Sweden and the Chronology and Stratigraphy of the Surroundings. GeografiskaAnnaler, 91A, 205-213. https://doi.org/10.1111/j.1468-0459.2009.00364.x

[4] Mörner, N.-A. and Lind, B.G. (2010) A Mediterranean Trading Centre in Southeast Sweden. In: Paraminopoulos, S.P., Ed., The Atlantis Hypothesis-Commentary, Heliotopos Publication, Athens, 685-699.

[5] Mörner, N.-A. (2012) Strict Solar Alignment of Bronze Age Rock Carvings in SE Sweden. Journal of Archaeological Science, 39, 3301-3305.

https://doi.org/10.1016/j.jas.2012.05.027

[6] Mörner, N.-A. and Lind, B.G. (2012) Stonehenge Has Got a Younger Sister. Ales Stones Decoded. International Journal of Astronomy and Astrophysics, 2, 23-27. https://doi.org/10.4236/ijaa.2012.21004

[7] Mörner, N.-A. and Lind, B.G. (2013) The Bronze Age in SE Sweden-Evidence of 
Long-Distance Travel and Advanced Sun Cult. Journal of Geography and Geology, 5, 78-91. https://doi.org/10.5539/jgg.v5n1p78

[8] Mörner, N.-A. and Lind, B.G. (2015) Long-Distance Travel and Trading in the Bronze Age: The East Mediterranean-Scandinavian Case. Archaeological Discovery, 3, 129-139. https://doi.org/10.4236/ad.2015.34012

[9] Mörner, N.-A. (2015) Ales Stones in SE Sweden: A Solar Calendar from the Late Bronze Age. Journal of Archaeological Sciences: Reports, 2, 437-448. https://doi.org/10.1016/j.jasrep.2015.04.002

[10] Mörner, N.-A., Lind, B.G. and Henriksson, G. (2018) A Golden Calendar from the Bronze Age. Archaeological Discovery, 6, 53-61. https://doi.org/10.4236/ad.2018.62004

[11] Mörner, N.-A. and Lind, B.G. (2018) Astronomy and Sun Cult in the Swedish Bronze Age. International Journal of Astronomy and Astrophysics, 8, 143-162. https://doi.org/10.4236/ijaa.2018.82010

[12] Petersen, H. (1875) Om Hellristninger i Denmark. Aabøger for nordisk Oldkyndighed og Historie.

[13] Glob, P.V. (1969) Hellristninger i Danmark. Gyldendals.

[14] Ifrah, G. (1994) Histoire Universelle des Chiffes. Robert Laffont, Bouquins.

[15] Henriksson, G. (2018) Personal Communications, September 25, 2018, Applying His Model Presented in Advances in Astrophysics, 2, 184-196 (2017).

[16] Adam of Brehmen (1075/76) Gesta Hammaburgensis Ecclesiae Pontificum.

[17] Struve, K.V. (1957) Die Kultur der Bronzezeit in Schleswig-Holstein. Schleswig-Holstein Landesmuseum, Hefte 8, Karl Wachholtz Verlag, Neumünster.

[18] Goldscheibe Glüsing. http://www.museum-albersdorf.de/poster/goldscheibe.htm 